\title{
Sprawozdanie: Przyczyny, decyzje, interwencje - ogólnopolskie seminarium dotyczące przyczyn, form i narzędzi wsparcia w kryzysie bezdomności młodzieży i młodych dorosłych (Kazimierz Dolny 19-21 maja 2019)
}

\begin{abstract}
Abstrakt
W maju 2019 r. odbyło się seminarium „Przyczyny, decyzje, interwencje - ogólnopolskie seminarium dotyczące przyczyn, form i narzędzi wsparcia w kryzysie bezdomności młodzieży i młodych dorosłych", którego głównym organizatorem była Fundacja po DRUGIE. Specjaliści ze służb reintegracji społecznej spotkali się w Kazimierzu Dolnym, by omówić zjawisko kryzysu bezdomności młodzieży i młodych dorosłych, zwłaszcza wśród osób opuszczających instytucje opiekuńczo-wychowawcze oraz resocjalizacyjne. Dlaczego wciąż spotykamy się z tym, iż nastolatkowie żyją na ulicy? Czy system rzeczywiście wspiera ich w sposób prawidłowy? Na to pytanie starali się odpowiedzieć prelegenci seminarium, wspierając się doświadczeniami uczestników spotkania, którzy na co dzień pracują z młodzieżą, której losy po wyjściu z placówki często koncentrują się na przetrwaniu na ulicy - bez wsparcia oraz możliwości na rozwiązanie kryzysu.
\end{abstract}

Słowa kluczowe: seminarium, bezdomność, młodzież w kryzysie bezdomności, usamodzielnienie, pomoc instytucjonalna.

\footnotetext{
*Fundacja po DRUGIE.
} 


\title{
Report: Causes, Decisions, Interventions - a Nationwide Seminar on the Causes, Forms and Tools of Support in the Crisis of Homelessness of Teenagers and Young Adults (Kazimierz Dolny 19-21 of May 2019)
}

\begin{abstract}
In May 2019, a seminar entitled "Causes, decisions, interventions - a nationwide seminar on the causes, forms and tools of support in the crisis of homelessness of teenagers and young adults" took place, organized by the po DRUGIE Foundation. Specialists from social reintegration services met in Kazimierz Dolny to discuss the crisis of homelessness of teenagers and young adults, especially among people leaving institutions such as foster care or rehabilitation centers. Why do we still face the problem of teenagers living on the street? Does the system support them properly? These questions were answered by lecturers at the seminar. They were supported by participants in the meeting, who shared experiences of their daily work in institutions with teenagers whose lives after leaving an institution are often focused on survival on the street, with no support or opportunities to solve the crisis.
\end{abstract}

Keywords: seminar, homelessness, youth homelessness, independence process, institutional help.

W XXI w. wciąż borykamy się ze zjawiskiem bezdomności, które dotyczy również osób dopiero wkraczających w dorosłość. 0 tym, dlaczego młodzież doświadcza życia na ulicy oraz jak można wspierać młodych ludzi w wychodzeniu z bezdomności dyskutowali specjaliści podczas seminarium w Kazimierzu Dolnym. Spotkanie zatytułowane: „Przyczyny, decyzje, interwencje - ogólnopolskie seminarium dotyczące przyczyn, form i narzędzi wsparcia w kryzysie bezdomności młodzieży i młodych dorosłych" zorganizowane zostało przez Fundację po DRUGIE z Warszawy we współpracy z Fundacją na Rzecz Rozwoju Probacji „PROBARE”, Wydziałem Nauk o Wychowaniu Uniwersytetu Łódzkiego, Zakładem Kryminologii Instytutu Prawa Karnego Wydziału Prawa i Administracji Uniwersytetu Warszawskiego, Stowarzyszeniem Sędziów Rodzinnych Pro Familia oraz Fundacją ATALAYA.

Punktem wyjścia dla potrzeby zorganizowania spotkania było pytanie o przyczyny i oblicza bezdomności wśród młodych osób (często osób opuszczających placówki opiekuńczo-wychowawcze i resocjalizacyjne). Celem seminarium było omówienie już istniejących w Polsce narzędzi wsparcia i dobrych praktyk, ale również próba odpowiedzi na pytanie o to, co powinno się zmienić, by uniknąć sytuacji, w których 18-19-letni człowiek znajduje się bez dachu nad głową. Jak przeciwdziałać bezdomności młodzieży? Jak rozpoznawać jej symptomy i jak interweniować?

Seminarium skupiło przedstawicieli służb reintegracji społecznej, którzy na co dzień pracują z młodzieżą w trudnej sytuacji życiowej, oraz pracowników sądow- 
nictwa i naukowców. W ciągu trzech dni w spotkaniu udział wzięło ponad sto osób. Seminarium zostało podzielone na dwie części. Pierwsza dotyczyła form i narzędzi wsparcia młodzieży w kryzysie bezdomności, druga natomiast zatytułowana została następująco: „Zanim młodzież staje w obliczu bezdomności...”. Warto dodać, że oprócz konwencjonalnych wystąpień i dyskusji, organizatorzy zaproponowali ciekawą formułę sprzyjającą wypracowaniu wniosków. W programie seminarium określona ona została mianem „Nocnych rozmów” i umiejscowiona została w czasie po kolacji. Spotkanie to zatytułowane było: „Wokół nierówności w traktowaniu kobiet i mężczyzn w kryzysie bezdomności" i prowadzone przez dr hab. Monikę Płatek, prof. UW i prezeskę fundacji po DRUGIE - Agnieszkę Sikorę.

W dalszej części odniosę się do trzech kluczowych zagadnień, jakie wyznaczały kierunek dyskusji (przyczyn bezdomności młodych ludzi, dylematów specjalistów i podopiecznych związanych $\mathrm{z}$ instytucjonalnym systemem pomocy oraz istniejących narzędzi w zakresie przeciwdziałania problemom). Odniosę się do wybranych i przywołam tylko niektóre wystąpienia z seminarium w danym zakresie.

\section{Przyczyny}

Seminarium rozpoczęła Agnieszka Sikora wystąpieniem pod znaczącym tytułem: „Nie masz nic, możesz wszystko - spotkanie z młodzieżą w kryzysie bezdomności”. Nakreśliła w nim najważniejsze problemy, z jakimi przychodzi się mierzyć na co dzień młodym ludziom, którzy zwracają się o pomoc i wsparcie do Fundacji po DRUGIE. Są to osoby, które choć znajdują się na początku swojej dorosłości, to dźwigają bagaż wielu negatywnych doświadczeń życiowych, niepowodzeń w relacjach z innymi ludźmi i traum. Borykają się z problemami zaburzeń psychicznych, uzależnień i są w stanie kryzysu bezdomności. Mimo że przeszły bardzo bogatą drogę instytucjonalną, czują się osamotnieni, a ich problemy są nawarstwione i dotyczą właściwie każdej sfery życia. Bywa, że szukają w fundacji nie tylko wparcia dla pokonania swoich problemów życiowych, ale stworzenia jakiegokolwiek programu i dania szansy na dalsze przeżycie.

By znaleźć jak najlepsze rozwiązanie problemów i stworzyć ofertę dla osoby w kryzysie bezdomności, czasem trzeba usłyszeć wiele wersji jednej historii, jednego przypadku. Szczególnie poruszające jest to, że znaczną część osób w kryzysie bezdomności stanowią (byli) podopieczni instytucji wychowawczych i opiekuńczych (począwszy od pieczy zastępczej, kończąc na ośrodkach resocjalizacyjnych). Przyglądanie się historiom ich życia to śledzenie losów dziecka, nastolatka, a następnie młodego dorosłego, który „wędruje” po systemie pomocy społecznej, od instytucji do instytucji. Skoro istnieje wiele wyspecjalizowanych ośrodków i miejsc, to dlaczego uczestnicy seminarium stają przed pytaniem: dlaczego w XXI w. istnieje problem kryzysu bezdomności młodzieży i młodych dorosłych? W trakcie dyskusji pytanie to zostało zmienione na następujące: gdzie znajduje się 
luka w systemie, która powoduje przeciwstawne efekty działań w stosunku do założonych celów?

Specjaliści z różnych dziedzin podczas swoich wystąpień próbowali odpowiedzieć na to pytanie. Co ważne, wnioski z tych wystąpień były formułowane wspólnie z publicznością. Licznymi uczestnikami seminarium były bowiem osoby, które na co dzień tworzą system, który był analizowany - pracownicy domów dziecka, młodzieżowych ośrodków wychowawczych, noclegowni, organizacji charytatywnych, świetlic środowiskowych itd. Pracując bezpośrednio z osobami zagrożonymi bezdomnością (lub organizując tę pracę), mają największe pole możliwości do działania z młodzieżą doświad czającą trudnej sytuacji.

Pytanie o przyczyny bezdomności młodzieży (mimo rozbudowanego systemu wsparcia instytucjonalnego) powracało przez całe seminarium. Można ich upatrywać w rodzinie (dysfunkcyjnej, obarczonej problemami czy uzależnieniem), można jednak iść dalej i szukać luk w systemie, który bywa raczej nadzorujący i kontrolujący niż wspierający w rozwiązywaniu problemów konkretnego człowieka. W wystąpieniach i głosach $\mathrm{w}$ dyskusji uczestników seminarium wątek nadzoru i kontroli zamiast życzliwego wsparcia pojawiał się wiele razy. Jednym z wniosków był taki, że istniejący system „nie zapewnia” pozytywnego dorosłego w życiu młodych ludzi, który potrafiłby być realnym wsparciem w budowaniu ich samodzielności i niezależności od wsparcia instytucji.

Pytanie o przyczyny było stawiane również przy prezentacji różnorodnych form wsparcia dla młodzieży, która jest zagrożona bezdomnością bądź znajduje się już w kryzysie bezdomności. Zauważony został tu następujący problem: czy dana forma pomocy jest zasadna, biorąc pod uwagę wiek potencjalnych beneficjentów? Pytanie to jest niezwykle ważne, jeśli wziąć pod uwagę to, że bezdomność w Polsce najczęściej odbierana jest jako problem dotykający osób w średnim wieku. Większość stereotypowych wyobrażeń człowieka w kryzysie bezdomności skupia się wokół obrazu osoby z problemami zdrowotnymi, fatalną higieną osobistą oraz uzależnieniami. Gdzie w takim wyobrażeniu miejsce dla 18-19-latka?

„Bezdomność młodzieży nie jest postrzegana jako odrębny problem społeczny" - mówiła Małgorzata Sabalska z Fundacji po DRUGIE, jedna z organizatorek seminarium.

To, z czym mierzą się młodzi w kryzysie, jest nieco różne od doświadczeń osób w wieku średnim, które spędziły kilka, kilkanaście lat na ulicy. Młodzież ma więcej szans oraz możliwości, gdyż jeszcze nie doświadczyła całego przekroju konsekwencji, które wiążą się z długoletnim pobytem na ulicy. Jest na początku tej drogi, a naszą rolą jest jej ochrona, by nie doświadczyła negatywnych rzeczy. By to osiągnąć, potrzebne są odrębne narzędzia wsparcia, ale przede wszystkim podejście uwzględniające potrzeby rozwojowe, zasoby, a także ograniczenia.

Czy zatem oferta, która istnieje w ramach systemu wsparcia osób w trudnej sytuacji, realnie odpowiada na potrzeby młodzieży bez dachu nad głową? 0 tym 
mówili prelegenci seminarium, rozważając różne etapy i szczeble systemu pomocowego związanego z kryzysem bezdomności.

Marta Czapnik z Wydziału Stosowanych Nauk Społecznych i Resocjalizacji Uniwersytetu Warszawskiego przybliżyła Europejską Typologię Bezdomności i Wykluczenia Mieszkaniowego (ETHOS), odnosząc ją również do polskich uwarunkowań oraz danych statystycznych. Zobrazowanie różnych form bezdomności - nie tylko tych najbardziej widocznych dla społeczeństwa - pozwoliło na zrozumienie, jak obszerny jest problem braku bezpiecznego oraz stabilnego zamieszkania. Warto podkreślić, iż w Polsce nie stosuje się określenia „bezdomnych dzieci” - mimo iż w Domach Samotnej Matki bądź ośrodkach terapeutycznych mieszkają dzieci oraz młodzież. Co więcej, tym osobom w trakcie usamodzielnienia nie przysługuje żadne dodatkowe wsparcie, gdyż nie spełniają tzw. warunków brzegowych. W momencie ukończenia 18. roku życia dzieci bezdomnych rodziców są pozostawione same sobie. Dla porównania, osoby opuszczające pieczę zastępczą bądź ośrodki opiekuńczo-wychowawcze przynajmniej w myśl litery prawa mogą liczyć na wsparcie finansowe ze strony państwa, jak i również pomoc w postaci opiekuna-specjalisty, gdy realizują Indywidualny Plan Usamodzielnienia (IPU).

Warto dodać, że podczas seminarium obszar dotyczący samego procesu usamodzielniania był tematem żywych dyskusji, gdyż bezpośrednio wiąże się to zagadnienie z pytaniem odnoszącym się do osiągnięcia pełnoletności przez wychowanków placówek - co dalej się z nimi dzieje? Czy rzeczywiście narzędzie w postaci Indywidualnego Programu Usamodzielnienia przynosi wymierne rezultaty?

\section{Decyzje}

Ireneusz Stawiński z Zakładu Poprawczego w Falenicy oraz dr Małgorzata Dziewanowska, prawniczka z Uniwersytetu Warszawskiego (obydwoje związani z Fundacją po DRUGIE) szeroko omawiali zagadnienie IPU na dwóch płaszczyznach: badawczej - poprzez analizę dokumentów IPU oraz praktycznej - z perspektywy osoby je tworzącej i realizującej. Głównym i silnym przesłaniem wynikającym z doświadczeń prelegentów było stanowisko, iż proces usamodzielnienia powinien rozpoczynać się od pierwszego dnia pobytu w placówce. Winien być traktowany jako stopniowe przygotowanie wychowanka do jej opuszczenia i pracy nad niezależnością. W rzeczywistości często prace nad usamodzielnieniem są podejmowane kilka miesięcy bądź nawet miesiąc przed osiągnięciem pełnoletności wychowanka. Powstaje więc pytanie: czy rzeczywiście plany budowane na "ostatnią chwilę" pozwalają na stworzenie realistycznej wizji przyszłości uwzględniającej zasoby i możliwości podopiecznego?

Problematyczną kwestią jest również wybór opiekuna usamodzielnienia. Najczęściej są to wychowawcy z placówek. Warto zastanowić się, czy jest to wybór właściwy i czy rzeczywiście opiekun usamodzielnienia będzie mógł pełnić rolę 
pozytywnego dorosłego, który towarzyszy, wspiera i motywuje do podejmowania rozsądnych i konstruktywnych działań. Dlaczego? Po pierwsze, często po opuszczeniu placówek byli wychowankowie nie chcą utrzymywać dalszych kontaktów z instytucją, którą opuścili - chcą się odciąć od tego rozdziału w swoim życiu, a nawet dobra relacja i więź z wychowawcą nie sprawi, że nie będą go kojarzyć z systemem pieczy zastępczej. Po drugie, młodzież (zwłaszcza z placówek resocjalizacyjnych) po osiągnięciu pełnoletności wraca do swoich rodzinnych stron. Często są one położone nawet kilkaset kilometrów od placówki. Czy w takiej sytuacji można mówić o bieżącym wsparciu i utrzymywaniu kontaktu, zwłaszcza że do danej instytucji trafiają kolejne dzieci wymagające uwagi wychowawcy?

Pytania i dyskusje dotyczące obszaru usamodzielnienia były bardzo żywe. Prowadziły do kolejnych wniosków: IPU często bywa fikcją, a jego „jakość" ma wpływ na dalsze losy wychowanka (szczególnie tego, który nie ma wsparcia wśród rodziny, nie posiada zasobów do osiągnięcia niezależności bez wsparcia instytucji). Tak więc, czy młody człowiek opuszczający mury instytucji ma szansę na dobry start? Szczególnie ciekawych odpowiedzi na to pytanie udzielali i pracownicy schronisk dla osób bezdomnych, organizacji prowadzącej mieszkania treningowe oraz przedstawiciele służby kuratorskiej i systemu sprawiedliwości. Zaniedbania systemu, luki prawne, „chodzenie na skróty”, koncentracja na dokumentach w miejsce pracy z człowiekiem, niewystarczająca współpraca interdyscyplinarna powodują, że młody człowiek zdobywa kolejne trudne doświadczenie „pomocy instytucjonalnej" i trafia do schroniska dla bezdomnych czy aresztu śledczego lub podejmuje ryzykowne zachowania. Konsekwencje niesprawnego systemu ponosi człowiek na progu dorosłości, który nie ma możliwości, by rozwiązać kryzys samodzielnie i bez wsparcia. Elżbieta Szadura-Urbańska, psycholożka z Fundacji po DRUGIE, w swoim wystąpieniu podkreślała właśnie to, iż etap bezdomności w życiu młodego dorosłego i radzenie sobie z kryzysem w sposób destruktywny jest często pokłosiem wcześniejszych zaniedbań oraz doświadczeń. Analizując uwarunkowania porażek w relacjach młodego człowieka z instytucjami wsparcia, czasem trudno się dziwić temu, że część młodzieży opuszczającej placówki trafia na ulicę i próbuje radzić sobie z sytuacją wedle posiadanych zasobów oraz możliwości. Najczęściej owo samodzielne „radzenie sobie” pogłębia już istniejące problemy.

\section{Interwencje}

Trudno jest określić liczbę młodzieży w kryzysie bezdomności w Polsce. Z wystąpień prelegentów wynika, że istnieją szacunki, wedle których osób do 26. roku życia bez stałego oraz stabilnego zakwaterowania jest niecałe 2 tys. Gdyby jednak spojrzeć na te obliczenia przez pryzmat metodyki, to uwagę zwraca fakt, iż ogólnopolskie badanie osób bezdomnych w 2019 r. realizowane przez Ministerstwo Rodziny, Pracy i Polityki Społecznej było przeprowadzone głównie w instytucjach 
oraz schroniskach. Nasuwa się więc wniosek, że szara strefa młodych, którzy nie korzystają ze wsparcia instytucjonalnego, może być kilkakrotnie wyższa. Uczestnicy seminarium wielokrotnie podkreślali, że często młodzież nie jest zainteresowana uzyskaniem pomocy od instytucji i nie zawsze potrafi odnaleźć się w miejscu, w którym średnia wieku użytkowników waha się od 40 do 55 lat. Pojawia się pytanie: czy pomoc noclegowni jest właściwym narzędziem wspierającym młodego człowieka w wychodzeniu z kryzysu?

Emilia Wesołowska, reprezentująca warszawski ośrodek „Tylko” prowadzony przez Caritas, nakreślała współczesny obraz i funkcjonowanie schronisk, wskazując, iż często udzielenie schronienia nie jest wystarczającą ofertą - młodzież potrzebuje większego wsparcia, uwagi oraz dostosowywania zasad i zindywidualizowanego programu pracy. Najtrudniejszym wyzwaniem dla pracownika socjalnego czy też psychologa jest wzbudzenie pewnej „iskierki”, motywacji do działania i przede wszystkim wiary w to, iż z kryzysu można wyjść i że jest jeszcze czas i możliwości na budowanie nowego życia i pełnej samodzielności.

Uczestnicy seminarium wskazywali na pewne pozytywne rozwiązania. „Małymi krokami" są wprowadzane nowe formy pomocy dla młodzieży doświadczającej życia na ulicy - poprzez domy młodzieżowe, mieszkania treningowe dla młodych dorosłych oraz indywidualne wsparcie w postaci asystentury osoby bezdomnej. Narzędzia te oraz innowacyjne podejścia mogą w szerszej perspektywie przekształcić się w standardowe formy wspierania osób młodych pod warunkiem, że problem bezdomności wśród młodzieży będzie brany pod uwagę jako zjawisko specyficzne, wymagające zmian w całym systemie oraz ofercie pomocy społecznej.

To, co udało się osiągnąć na seminarium, to przede wszystkim zwrócenie uwagi i pochylenie się nad problemem młodzieży i młodych dorosłych. Uczestnicy seminarium zgodnie twierdzili, że dyskusje uruchomiły pewne zmiany myślenia oraz nowe spojrzenia na problem bezdomności. Trzeba też zwrócić uwagę, że krytyczne spojrzenie na system często przez osoby go reprezentujące jest odbierane jak atak w ich pracę. Taki odbiór utrudnia dyskusję, jednak w Kazimierzu dzięki dużej otwartości, stworzeniu przez organizatorów warunków do spokojnej i konstruktywnej rozmowy udało się znaleźć zrozumienie również dla trudnych tematów. 